Diabetologia $9,376-379(1973)$

by Springer-Vorlag 1973

\title{
Effects of Adrenalectomy on the Obese-Hyperglycemic Syndrome in Mice (Gene Symbol ob)
}

\author{
P. Naeser \\ Departments of Pathology and Histology, University of Uppsala, Uppsala, Sweden
}

Received: December 9,1972 , and in revised form: April 28, 1973

Summary. Mice with the inherited obese-hyperglycemic syndrome (gene symbol $o b$ ) and their lean litter mates were adrenalectomized and then studied for up to $30-36$ weeks with regard to their body weights and the serum glucose and immunoreactive insulin level. Sham operated obese and lean mice were used as controls. Adrenalectomy did not prevent the excessive weight gain of the obese mice. However, during the first three weeks after adrenalectomy the mean weight increase was somewhat smaller than in the sham operated controls. The increase in the body weights of the lean animals was, however, not affected. The most prominent finding after adrenalectomy was a decrease of the serum levels of glucose and insulin in both obese and lean animals. The results indicate that in the obese mice adrenalectomy decreases the pronounced insulin resistance. It is also suggested that insulin resistance may be dissociated from the development of obesity in these animals.

Key words: Obese-hyperglycemic syndrome, obob mice, adrenalectomy, obesity, serum glucose, serum insulin, insulin resistance.
The recessively inherited obese-hyperglycemic syndrome in mice is characterized by a pronounced obesity, hyperglycemia (Ingalls et al., 1950; Westman, 1968; Genuth, 1969) and greatly enlarged islets of Langerhans (Gepts et al., 1960; Hellman et al., 1961; Hellerström et al., 1962 a). An additional feature of the syndrome is a marked enlargement of the adrenal glands, which has been attributed mainly to cortical hyperplasia (Hellerström et al., $1962 \mathrm{~b}$ ). To date it has not been clarified as to what extent this latter anomaly contributes to the other manifestations of the obesehyperglycemic syndrome. The observation that cortical hyperplasia was diminished when the caloric intake of the mice was restricted was interpreted to suggest that hyperadrenocorticism is not a primary aetiologic factor (Hellerström et al., 1962b). In addition, Mayer et al. (1953) reported that after bilateral adrenalectomy obese-hyperglycemic mice continued to gain weight although their blood glucose levels were temporarily decreased. The findings of Hausberger (1958) that high circulating corticosteroid levels in mice cause both obesity and an increase in number of pancreatio B-cells support the view that the enlarged adrenals may be of significance for the metabolic disturbances in the obesehyperglycemic syndrome.

The present study was designed to evaluate further whether hyperadrenocorticism is of etiological significance for the development of the obese-hyperglycemic syndrome in mice. For this purpose the effect of adrenalectomy on the obesity and circulating levels of glucose and insulin was followed in both obese mice and their lean litter mates.

\section{Material and Methods}

Thirty-eight male obese-hyperglycemic mice (gene symbol $a b$ ) and 40 of their lean male litter mates were used. The animals, which were 2 months old at the start of the experiment, belonged to a colony originating from Bar Harbor, Maine, U.S.A. and bred at the Department of Histology, University of Uppsala, Sweden since 1959. The mice were kept in plastic cages in a windowless temperature regulated room $\left(24+2^{\circ} \mathrm{C}\right)$ artificially illuminated between $7 \mathrm{a} . \mathrm{m}$. and 7 p.m. Free access to pelleted. food (kcal/g: carbohydrate 2.15 , protein 0.92 , fat 0.38 ) and water was allowed (cf. Westman, 1968). Operations and handling of the animals were always performed be. tween 7 and 11 a.m. Altogether 29 obese and 30 lean mice were adrenalectomized, while 9 obese and 10 lean animals were sham operated and served as controls.

Adrenalectomy was performed bilaterally by the dorsal route under light ether anesthesia using a modification of the method described by Gaunt (1933). The adrenals were easily identified and carefully extirpated in order not to damage the capsule. In the sham operated controls the adrenals were exposed but left intact. The wounds were closed with agraffes. The whole procedure took approximately $4 \mathrm{~min}$. A quick operation was found essential especially for the survival of the obese mice. Every 12 th $h$ during the first 36 post operative hours the adrenalectomized animals were injected intraperitoneally with $100 \mu \mathrm{g}$ corticosterone (Merck) in $100 \mu \mathrm{l} 0.9 \%$ (w/v) saline (NaCl). The sham operated controls were injected with the same volume of saline. The adrenalectomized animals were given a $0.45 \%$ solution of $\mathrm{NaCl}$ to drink.

Body weights were measured on a balance with a sensitivity of $\pm 0.1 \mathrm{~g}$. Blood samples were obtained from the orbital vein plexus and the blood was collected in clean dry test tubes and allowed to elot at room tempera. ture. After centrifugation, the serum was removed frozen and stored at $-18^{\circ} \mathrm{C}$ until assayed.

Glucose determinations were performed on duplicate serum samples $(5 \mu \mathrm{l})$ by a glucose oxidase method (Hjelm. et al., 1963). A separate blank without glucose oxidase was run for each sample. The error of a single determination was $\pm 3 \%$.

Serum insulin was determined immunologically with a double antibody radioimmunoassay technique (Hales and Randle, 1963) using crystalline mouse insulin as standard (biological and immunological activity $23 \mathrm{U} / \mathrm{mg}$ ). For satisfactory determination a minimal concentration of $\mathbf{0 . 3}$ $\mathrm{ng} / \mathrm{ml}$ was required. The error for a single determination. was $\pm 10 \%$. 
Thirty to 36 weeks after operation the animals were killed by cervical dislocation. The abdominal cavity was searched thoroughly for regenerated or ectopic adrenal tissue. The presence of such tissue was checked by histological examination.

\section{Results}

After adrenalectomy $\mathbf{1 6}$ obese-hyperglycemic mice and 18 lean litter mates survived throughout the full period of observation. The corresponding numbers for the sham operated animals were 7 and 9
The body weights of the animals in the four experimental groups are given in Table 1 . After 3 weeks the weight gain of the adrenalectomized obese mice was only $0.8 \pm 1.0 \mathrm{~g}$ and significantly lower than that of the sham operated obese controls $(5.7 \pm 0.9 \mathrm{~g} ; P<0.01)$. At the end of the observation period the increase in body weight of the adrenalectomized obese mice was $9.4 \pm 7.2 \mathrm{~g}$ as compared to $18.7 \pm 2.9 \mathrm{~g}$ in the sham operated controls $(P>0.05)$. Adrenalectomy had no influence on weight gain of the lean animals.

As can be seen in Table 2 both types of mice showed lower serum glucose levels after adrenaleotomy. In the

Table 1. Body weight of all adrenalectomized and sham operated mice at various times after operation. Numbers of obserm vations given within parentheses. Mean values $\perp$ S.E.M.M.

\begin{tabular}{|c|c|c|c|c|c|c|c|}
\hline \multirow{2}{*}{\multicolumn{2}{|c|}{$\begin{array}{l}\text { Body weight }(\mathrm{g}) \\
\text { animals }\end{array}$}} & \multirow[t]{2}{*}{ operation } & \multicolumn{5}{|c|}{ time after operation (weeks) } \\
\hline & & & 0 & 1 & 2 & 3 & $30-36$ \\
\hline \multirow[t]{2}{*}{ obese } & $(7)$ & adr. etc. & $42.5 \pm 2.2$ & $40.8 \pm 2.1$ & $42.0 \pm 2.5$ & $43.3 \pm 2.2$ & $51.9 \pm 5.8$ \\
\hline & (7) & sham op & $37.0 \pm 2.6$ & $38.2 \pm 2.9$ & $40.6 \pm 2.7$ & $42.8 \pm 2.6$ & $55.8 \pm 2.5$ \\
\hline \multirow{2}{*}{ lean } & (13) & adr. ect. & $25.1 \pm 0.6$ & $25.7 \pm 0.5$ & $26.4 \pm 0.5$ & $26.7 \pm 0.5$ & $32.5 \pm 0.6$ \\
\hline & (9) & sham op & $25.2 \pm 1.0$ & $25.9 \pm 1.0$ & $26.5 \pm 0.9$ & $27.3 \pm 1.0$ & $32.2 \pm 1.4$ \\
\hline
\end{tabular}

Table 2. Serum glucose levels of all adrenalectomized and sham operated mice at varions thmes after operation. Numbers of observations given within parentheses. Mean values IS.E.M.

\begin{tabular}{|c|c|c|c|c|c|c|c|}
\hline \multicolumn{8}{|c|}{$\begin{array}{l}\text { Serum glucose (rag per } 100 \mathrm{ml}) \\
\text { animals }\end{array}$} \\
\hline & & & \multicolumn{2}{|l|}{$\overline{0}$} & 2 & 3 & $30-36$ \\
\hline obese & $\begin{array}{l}(7) \\
(7)\end{array}$ & $\begin{array}{l}\text { adr. ect. } \\
\text { sham op }\end{array}$ & $\begin{array}{l}241 \pm 50 \\
241+46\end{array}$ & $\begin{array}{l}120 \pm 9^{b} \\
247+38^{2}\end{array}$ & $\begin{array}{l}114 \pm 7^{a} \\
230+48\end{array}$ & $\begin{array}{r}80 \pm 10^{\mathrm{b}} \\
184 \pm 34\end{array}$ & $\begin{array}{l}79 \pm 6 \\
80+10\end{array}$ \\
\hline lean & (13) & adr. ect. & $123 \pm 6$ & $108 \pm 4$ & $103 \pm 5^{b}$ & $69 \pm 7 \mathrm{~b}$ & $81 \pm 3$ \\
\hline & (9) & sham op & $141 \pm 12$ & $118 \pm 6$ & $126 \pm 6$ & $105 \pm 3$ & $102 \pm 6$ \\
\hline
\end{tabular}

a $P<0.05$ as compared to sham operated controls.

b $P<0.01$ as compared to sham operated controls.

Table 3. Serum insulin levels of all adrenalectomized and sham operated mice at various times after operation. Numbers of observations given within parentheses. Mean values \pm S.E.M.

\begin{tabular}{|c|c|c|c|c|c|c|}
\hline \multicolumn{7}{|c|}{$\begin{array}{l}\text { Serum insulin (ng per ml) } \\
\text { animals }\end{array}$} \\
\hline & & & $\overline{0}$ & 1 & 2 & $30-36$ \\
\hline $\begin{array}{l}\text { obese } \\
\text { lean }\end{array}$ & $\begin{array}{r}(7) \\
(7) \\
(13) \\
(9)\end{array}$ & $\begin{array}{l}\text { adr. ect. } \\
\text { sham op } \\
\text { adr. eet. } \\
\text { sham op }\end{array}$ & $\begin{array}{r}192 \pm 83: \\
168 \pm 51 \\
11.6 \pm 2.9 \\
6.3 \pm 1.7\end{array}$ & $\begin{array}{c}35 \pm 9 \mathrm{a} \\
187 \pm 61 \\
5.1 \pm 1.0 \\
7.2 \pm 1.2\end{array}$ & $\begin{array}{c}39 \pm 13^{\mathrm{a}} \\
212 \pm 67 \\
6.1 \pm 1.0 \\
4.2 \pm 0.9\end{array}$ & $\begin{array}{l}18 \pm 4^{a} \\
77 \pm 27 \\
5.5 \pm 0.6 \\
3.1 \pm 0.3\end{array}$ \\
\hline
\end{tabular}

a $P<0.05$ as compared to sham operated controls.

: based on 4 observations.

respectively. Autopsy of the adrenalectomized mice at the end of the observation period revealed regenerated or ectopic adrenal tissue in 9 obese mice and 5 lean litter mates. Histological examination showed that the regenerated adrenal cortical tissue was normal in appearance. These animals displayed serum glucose and insulin values which rose to similar levels as in the sham operated controls and were excluded from the data. The residual material therefore consisted of 7 obese and 13 lean adrenalectomized mice. adrenalectomized obese group the values at 1, 2 and 3 weeks after the operation were significantly lower than in the controls. Thirty to 36 weeks after operation there was no longer any difference in serum glucose levels between the two groups of obese animals. This was obviously due to a drop in the serum glucose level of the sham operated controls, which most likely reflected an ageing process in these animals (cf. Westman, 1968). After the second postoperative week the adrenalectomized lean animals had a significantly lower mean 
serum glucose level than did the sham operated lean mice. This difference persisted throughout the rest of the observation period.

In the adrenalectomized obese animals the serum insulin level decreased markedly (Table 3 ) within the first week after operation and this persisted throughout the period of observation. A reduction of the insulin level was noted also in the adrenalectomized lean litter mates one week after adrenalectomy $(P<0.05)$.

It is also evident that at all times after adrenalectomy there were significantly higher circulating serum insulin levels in the obese than in the lean animals $(P<0.01)$.

\section{Discussion}

The present study demonstrates that adrenalectomy causes a marked reduction of circulating levels of glucose and insulin, but does not prevent excessive weight gain by obese-hyperglycemic mice. At the time of operation the animals were in a dynamic phase of the syndrome, when both the body weights and serum glucose and insulin levels are known to increase rapidly (Westman, 1968). The failure of adrenalectomy to arrest the weight gain is in agreement with the report of Mayer et al. (1953), who observed that removal of the adrenals did not result in a reduction of the body weight in an obese-hyperglycemic mouse. This is in contrast to results obtained in other strains of mice with inherited obesity. Excessive accumulation of fat did not occur in adrenalectomized $\mathrm{NH}$ and $\mathrm{A}^{y}$ a mice (Hausberger et al., 1960; Liebelt, 1963).

It has been shown previously that obesity in laboratory animals may be associated with increased adrenal weight, although this is variable. Thus, enlargement of the adrenal cortex has been reported with other varieties of hereditary obesity such as $\mathrm{NZO}, \mathrm{A}^{y} \mathrm{a}$ and NH mice (Bielschowsky et al., 1956; Hellerström et al., 1962 b; Hausberger et al., 1960). On the other hand, mice with the diabetic syndrome (gene symbol $d b$ ) have adrenal glands of normal size (Coleman et al., 1968). Moreover, in mice with obesity induced by hypothalamic lesions resulting from either goldthioglucose administration or electrolytic damage of the ventro medial nucleus, the adrenal weights are found to be unchanged (Marshall et al., 1957). The variation of adrenal weights found in different forms of obesity in mice makes it difficult to draw conclusions as to the precise aetiological significance of these glands for the development of obesity. The present finding that the body weights of the obese-hyperglycemic mice increased even in the absence of the adrenal glands suggest that adrenocortical steroids may not be of primary aetiological significance for this particular type of genetically induced obesity. Further support for this view comes from recent observations of elevated levels of circulating corticosteroids in the obese-hyperglycemic mice (Naeser, unpublished). On the other hand the presence of hyperadrenocorticism seems to influence the serum insulin concentration of the obesehyperglycemic mice and at least two possible mechanisms must be considered. First the insulin resistance of these animals might be changed. This is supported by the present finding that after adrenalectomy both the serum insulin and glucose levels were reduced in the obese animals probably reflecting a marked decrease of their insulin resistance. A lowered insulin resistance can also be induced by starving the animals (Batt et al., 1966) or by feeding them a carbohydrate free diet (Chlouverakis, 1971). It seems, however, unlikely that the decreased serum insulin levels observed here were caused by a state of starvation of the obese mice since their weight gain did not differ significantly from that of their controls. The view that hyperfunction of the adrenal glands contributes to the disturbed carbohydrate metabolism of the obese-hyperglycemic mice gains further support from previous observations by Hausberger (1958), who found that subcutaneous implantation of dehydrocorticosterone or corticosterone pellets to mice resulted not only in enlarged islets of Langerhans but also in obesity. Further, administration of glucocorticoid to rabbits is reported to result in increased concentrations of serum insulin and morphological signs of functional stimulation of the islet B-cells (Volk et al., 1963; Berson et al., 1959). An alternative explanation would be that the corticosteroids directly affect the insulin secretion of the B-cells. Although such an effect cannot be excluded there is so far little evidence that corticosteroids directly modify the insulin release, at least in vitro (ef. Malaisse, 1969).

In conclusion, the present data suggest that hyperfunction of the adrenal glands may contribute to the insulin resistance of the obese-hyperglycemic mice. The observation that adrenalectomy did not prevent excessive weight gain in these animals also suggests that the development of obesity in these animals can occur also in the presence of a decreased insulin resistance.

Acknowledgements. This work was supported by the Medical Faculty of the University of Uppsala and The Swedish Medical Research Council (B73-12X-109-09B). The skilled technical assistance of Miss Astrid. Nordin is gratefully acknowledged.

\section{References}

Batt, R., Mialhe, P.: Insulin resistance of the inherently obese mouse. Nature 212, 289-290 (1966)

Bielschowsky, M., Bielschowsky, F.: The New Zealand strain of obese mice. Their response to stilboestrol and to insulin. Aust. J. exp. Biol. med. Sci. 34, $181-198$ (1956)

Coleman, D.L., Hummel, K.P.: Physiological and morphological lesions characterizing the mutation diabetes $(\mathrm{db})$ in the mouse. J. Diabétologie Hôtel-Dieu 9, 20-30 (1968)

Chlouverakis, C.: On the origin of hyperglycaemia in the obese-hyperglycemic mouse $(o b a b)$ : Effect of diet on blood glucose and serum insulin in $a b o b$ and gold-thioglucose obese mice. Diabetologia 7, $373-378$ (1971) 
Gaunt, R.: Adrenalectomy in the Rat. Amer. J. Physiol. $103,494-510(1933)$

Genuth, S.M.: Hyperinsulinism in mice with the genetically determined obesity. Endocrinology 84, 386-391 (1969)

Gepts, W., Christophe, J., Mayer, J.: Pancreatic islets in mice with the obese-hyperglycomic syndrome. Diabetes 9, $63-69(1960)$.

Hales, C.N., Randle, P.J.: Immunoassay of insulin with antibody precipitate. Biochem. J. 88, 137-146 (1963)

Hausberger, F.X.: Islet hypertrophy in obesity induced by corticosteroids. Fed. Proc. 17, 67 (1958)

Hausberger, F.X., Hausberger, B.: The etiologic mechanism of some form of hormonally induced obesity. Amer. J. clin. Nutr. 8, 671-681 (1960)

Hellman, B., Brolin, S. E., Hellerström, C., Hellman, K. The distribution pattern of the pancreatic islet volume in normal and hyperglycemic mice. Acta endocr. (Kbh) $36,609-616(1961)$

Hellerström, C., Hellman, B., Brolin, S., Larsson, S.: In vitro incorporation of thymidine- $\mathrm{H}^{3}$ in the pancreas of normal and obese-hyperglycemic mice. Acta path. microbiol. scand. 54, $1-8$ (1962a)

Hellerström, C., Hellman, B., Larsson, S.: Some aspects of the structure and histochemistry of the adrenals in obese-hyperglycemic mice. Acta path. microbiol. scand. $54,365-372(1962 b)$

Hjelm, M., Deverdier, C.H.: A methodological study of the enzymatic determination of glucose in blood. Scand. J. clin. Lab. Invest. 15, 415-428 (1963).

Ingalls, A.M., Dickie, M.M., Snell, G.D.: Obesity, a new mutation in the house mouse. J. Hered. 41, 317-318 (1950)

Liebelt, R.A.: Response of adipose tissue in experimental obesity as influenced by genetic, hormonal, and neuro. genic factors. Ann. N.Y. Acad. Sci. 110, 723-748 (1963)

Malaisse, W.: Ettude de la sécrétion insulinique in vitro. Editions Arscia. S.A. (1969)

Marshall, N.B., Andrus, S.W., Mayer, J.: Organ weights in three forms of experimental obesity. Amer. J. Phy. siol. $189,343-346$ (1957)

Mayer, J., Russell, R.E., Bates, M. W., Diekie, M. M. : Metabolic, nutritional and endocrine studies of the hereditary obesity-diabetes syndrome of mice and mechanism of its development. Metabolism 2, 9-21 (1953)

Volk, B.W., Lazarus, S.S.: Ultramicroscopic studies of rabbit pancreas during cortisone treatment. Diabetes 12, 162-173 (1963)

Westman, S.: Development of the obese-hyperglycemic syndrome in mice. Diabetologia 4, 141-149 (1968)

\author{
Dr. Peter Naeser \\ Department of Pathology I \\ Box 553 \\ S-75122 Uppsala \\ Sweden
}

